\title{
Assessment of Urban Forest Tree Species Population and Diversity in Ibadan, Nigeria
}

\author{
Aladesanmi D. Agbelade,", Jonathan C. Onyekwelu², Oluwaseun Apogbona1 \\ ${ }^{1}$ Department of Forestry, Wildlife and Fisheries Management, Faculty of Agricultural Sciences, Ekiti State University, Nigeria \\ ${ }^{2}$ Department of Forestry and Wood Technology, School of Agriculture and Agricultural Technology, Federal University of Technology, \\ Nigeria
}

Copyright $(2016$ by authors, all rights reserved. Authors agree that this article remains permanently open access under the terms of the Creative Commons Attribution License 4.0 International License

\begin{abstract}
This research focuses on the urban tree species population and diversity within Ibadan metropolis as a means of creating biodiversity database for the urban centre in South west, Nigeria. This was determined by assessing urban forest tree abundance, species diversity and growth yield. All trees with diameter at breast height $(\mathrm{dbh}) \geq 10 \mathrm{~cm}$ were identified, dbh measured and their frequencies taken in all the area enumerated within Ibadan. There are 155 tree stems belonging to 26 families and 54 tree species within Ibadan built-up areas and 101 tree stems belonging to 16 families and 19 tree species in peri-urban centre of Ibadan. The two most abundant species and families were Delonix regia of Fabaceae family and Terminalia ivorensis of Combretaceae family (18 and 17 stems) respectively while Fabaceae family has ( 7 species). The value of the Shannon's max diversity index $\left(\mathrm{H}_{\max }\right)$ of (3.99 and 2.94), Shannon-Wiener diversity index (3.35 and 2.48) and species evenness 0.84 were the same for peri-urban centre, while the growth variable were basal area and volume of $\left(22.8 \mathrm{~m}^{2}\right.$ and $\left.18.5 \mathrm{~m}^{2}\right)$ and $\left(284.8 \mathrm{~m}^{3}\right.$ and $\left.275.3 \mathrm{~m}^{3}\right)$ respectively. This study provide information on the level of tree species biodiversity due to infrastructure development that has reduced forest cover within the built-up areas of Ibadan which can expose the city to lot of environmental hazard.
\end{abstract}

Keywords Biodiversity Indices, Tree Species Diversity, Population, Urban and Peri-urban Forest

\section{Introduction}

Nigeria's population density presents a mix of an increasing growth rate and intense rural-urban migrations. This lead urban forest destruction and social amenities development which makes the urban centres attractive for high migration potentials. Urban forestry is the careful studies, monitoring, and management of urban forests, i.e. tree populations in urban settings for the purpose of improving the urban environment. It is also imperative to know that urban forest refers to all publicly and privately owned trees within an urban area, including individual trees along streets and in backyards, as well as stands of remnant forest (Nowak et al., 2001) [1]. Biodiversity includes the variety of different species (plants, animals - including humans, microbes and other organisms), the genes they contain, and the structural diversity in ecosystems. Keystone Center (1991) [2] defined biodiversity as the variety of life and all the processes that keep life functioning. Trees in urban areas provide numerous benefits such as public aesthetic appeal, the root of trees prevent erosion, trees improve air quality, serves as wind break, shelter belt, protect water flow, sequence carbon, ameliorate harsh weather condition, serves as raw materials to the wooden industries, preserve water shed, serve as recreation centres for relaxation and home garden as food. Urban forest provides numerous tangible environmental benefits that often go unrecognized as reported by (McPherson and Simpson 1999) [3]. In recent years, there has been increased research on quantification of ecosystem services, the direct benefits that urban forest ecosystem provides to people (Millennium Ecosystem assessment 2005) [4]. Research and enumeration of various urban forest benefits can create citizen awareness towards the values of urban forest within an area that is publicly owned forest, as well as provide a basis for management of such benefits. It will also be of help to know that urban biodiversity is influenced by the status of original surrounding ecosystems and these can be managed properly during constructions within the built-up environment which can influenced the economic, social and cultural values derived from urban forest. The home garden, street trees, estate trees can harbour significant biodiversity. Assessing the status and trends of tree species diversity population is essential for sustainable development, strategies and planning of the urban centres in Nigeria. 


\section{The Study Area}

This research was carried out in Ibadan, Oyo State Nigeria. It is the city at the junction of the savannah and the rain forest. It is the third largest metropolitan area, by population, in Nigeria after Lagos and Kano, with a population of 2.84million according to UN World Urbanization Prospects, 2010. Ibadan is located in south-western Nigeria in the south-eastern part of Oyo. Ibadan city lies on the geographical coordinates of $7^{\circ} 23^{\prime} 47^{\prime \prime} \mathrm{N}, 3^{\circ} 55^{\prime} 0^{\prime \prime} \mathrm{E}$, with abundance of human and natural resources. The city enjoys a tropical climate with two distinct seasons. These are the raining season (April-October) and the dry season (November-March). Temperature ranges between $25^{\circ} \mathrm{C}$ and $35^{\circ} \mathrm{C}$. Tropical forest exists in the south, while guinea savannah predominates in the northern peripheries. Ibadan lies about 30 miles $(48 \mathrm{~km})$ inside the northern boundary of the lowland rainforest zone of western Nigeria.

\section{Data Collection}

The data for this research was collected from Ibadan metropolitan city of Oyo State, Nigeria. Government owned Institutions (schools, public buildings, higher institutions), worship centres (Church and Mosque buildings), privately owned institutions (schools, public buildings, higher institutions, Hotels, recreation centres, parks and gardens), Street and link roads. The selection Ibadan city for this study was done purposefully due to the population density and the comercial significant of the city. Green areas within Ibadan metroplis was sampled by the measuremnet of the trees diameters at base, middle and top, diamerter at breast height and height with the aid of spiegel relaskop and girth tape. Coordinates were taken with hand-held Global Positioning System (GPS) in all the locations selected within Ibadan. All trees with diameter at breast height (dbh) greater than or equal to $10 \mathrm{~cm}$ were identified, dbh measured with Girth Tape, height measured with Spiegel Relaskop and their frequencies taken. Tree species identification was done using keys in flora manuals and match-up technique. For trees that could not be identified on the field, representative samples (leaves, fruits and bark) were collected and taken to the herbarium for identification. Identified woody trees were classified as species, family and biodiversity indices were computered.

\section{Data Analyses}

\section{Forest Structure and Tree Species Diversity}

All tree species within selected locations in Ibadan were selected and were assigned to families using Keay (1989) [5] as guide.

\section{Basal Area}

The basal area of all trees within Ibadan metropolis was calculated using the formula:

$$
\mathrm{BA}=(\text { лD2)/4 }
$$

where, $\mathrm{BA}=$ Basal area $\left(\mathrm{m}^{2}\right), \mathrm{D}=$ Diameter at breast height $(\mathrm{cm})$ and $л=$ pie (3.142). The total BA for each plot was obtained by adding all trees BA in the plot.

\section{Volume}

The volume of all trees within Ibadan metropolis was calculated using the Newton's formula (Hush et al., 2003) [6]:

$$
\mathrm{V}=(\mathrm{h} / 6)(\mathrm{Db}+4 \mathrm{Dm}+\mathrm{Dt})
$$

where, $\mathrm{V}=$ Tree volume $\left(\mathrm{m}^{3}\right), \mathrm{Db}, \mathrm{Dm}$ and $\mathrm{Dt}=$ tree cross-sectional area at the base, middle and top of merchantable height, respectively $\left(\mathrm{m}^{2}\right)$ and $\mathrm{h}$ tree height $(\mathrm{m})$. The equation is expressed as (2)

\section{Species Diversity Index}

Species diversity index shall be computed using the Shannon-Wiener diversity index equation (3); Kent and Coker, 1992; Guo et al., 2003)[9,10].

$$
\left.H^{\prime}=-\sum_{i=1}^{s} p_{i} \ln p_{i}\right)(
$$

Where: $\mathrm{H}^{\prime}=$ Shannon-Wiener diversity index; $\mathrm{S}=$ total number of species in the community; $\mathrm{pi}=$ proportion of $\mathrm{S}$ made up of the ith species; $\ln =$ natural logarithm.

\section{Species Relative Dominance}

Species relative dominance (RD (\%)), used in assessing relative space occupancy, will be estimated using equation (4) (Aidar et al., 2001) [8].

$$
\mathrm{RDo}=\left(\sum \text { Bai } \times 100\right) / \sum \text { Ban }
$$

Where: $\mathrm{Bai}=$ basal area of all trees belonging to a particular species $i$; Ban = basal area of all trees in a city.

\section{Importance Value Index}

The Importance Value Index (IVI) of each species shall be computed with the relationship: $(\mathrm{RD}+\mathrm{RDo}) / 2)($ Brashears et al., 2004) [7].

\section{Species Relative Density}

Species relative density, which is an index for assessing species relative distribution (Brashears et al., 2004) [7], was computed with equation (6).

$$
\mathrm{RD}=(\mathrm{ni} / \mathrm{N}) \times 100
$$

where: $\mathrm{RD}(\%)=$ species relative density; $\mathrm{ni}=$ number of individuals of species i; $\mathrm{N}=$ total number of all individual trees of all species in the entire community.

\section{Shannon's Maximum Diversity Index}

Shannon's maximum diversity index will be calculated using equation (7) (Guo et al., 2003) [10]

$$
\operatorname{Hmax}=\operatorname{In}(\mathrm{S})
$$


Where: Hmax $=$ Shannon's maximum diversity index; $\mathrm{S}=$ total number of species in the community

Shannon's equitability (EH), which is obtained using equation (8) (Kent and Coker, 1992) [9].

$$
\mathrm{EH}=\mathrm{H}^{\prime} / \mathrm{Hmax}=\sum \mathrm{Pi} \operatorname{In}(\mathrm{Pi}) / \operatorname{In}(\mathrm{S})
$$

Where: $\mathrm{H}^{\prime}=$ Shannon-Wiener diversity index; $\mathrm{S}=$ total number of species in the community; $\mathrm{pi}=$ proportion of $\mathrm{S}$ made up of the ith species; ln = natural logarithm; Hmax = Shannon's maximum diversity index; $\mathrm{S}$ is as defined as above

\section{Result}

Tree Species Distribution Pattern within Ibadan

Tree species relative abundance, frequency, diversity and diameter at breast height within Ibadan were computed with biodiversity and growth variables equations. A total number of individual tree was 155 and 101 stems, 25 and 16 families belonging to 54 and 19 species were enumerated (Table 1a, 1b). In total, fifty four (54 and 19) tree species were found in Ibadan in which Delonix regia of Fabacea family has the highest number of population with a frequency of eighteen (18), closely followed by Terminalia ivorensis of Combretaceae family has frequency of seventeen (17) and Azadirachta indica of Meliceae family has a frequency of fifteen (15) in Ibadan. The value of the Shannon's max diversity index $\left(\mathrm{H}_{\max }\right)$ of 3.99 and 2.94 , indicated relatively diverse tree species with Shannon-Wiener diversity index $\left(\mathrm{H}^{\prime}\right)$ of 3.35 and 2.48 and species evenness $\left(\mathrm{E}_{\mathrm{H}}\right)$ of 0.84 which was the same for peri-urban centre. These results revealed that the correlation between species richness and evenness are similar as suggested by Onyekwelu et al; (2007) [12] that Shannon's equitability revealed that species evenness in forest communities are similar which is collaborated by the difference between $\mathrm{H}^{\prime}$ and $\mathrm{H}_{\max }$. Biodiversity indices are computed to show the level of diversity and abundance of species in different locations with similar scale for comparison and the higher the value the greater the species richness within the locations.
Biodiversity indices and Growth Variables of tree species within Ibadan

The biodiversity indices and growth variables of tree species within Ibadan were computed. The value of the Shannon's max diversity index $\left(\mathrm{H}_{\max }\right)$ is $3.99,2.94$ while Shannon-Wiener diversity index $\left(\mathrm{H}^{\prime}\right)$ is $3.35,2.48$ and and equitability index, using Pielou's evenness index of 0.84 , 0.84 were obtained in (Table 4). The highest basal area and volume of trees within the city $\left(0.43 \mathrm{~m}^{2}\right.$ and $4.32 \mathrm{~m}^{3}$, respectively) were contributed by Delonix regia and Azadirachta indica. This was followed by Astonia boonei and Delonix regia with basal area and volume of $0.83 \mathrm{~m}^{2}$ and $8.53 \mathrm{~m}^{3}$, respectively. The least basal area and volume $\left(0.13 \mathrm{~m}^{2}\right.$ and $1.67 \mathrm{~m}^{3}$, respectively) were recorded for Eucalyptus torrelliana and Morinda lucida. However, Delonix regia had the highest species importance with an IVI of $9.39 \%$. This was closely followed by Azadirachta indica with IVI of 8.28. The families with the highest mean dhb $(177.4 \mathrm{~cm})$ and height $(18.8 \mathrm{~m})$ were Apocynaceae and Meliaceae, respectively. Ibadan metropolis contains variety of trees species which serve various purposes which include beautification, income generation, food supplements and medicinal purposes. Apart from beautification and medicinal values of trees, they also sequestrate carbon and this is beneficial to humans because excess of carbon in the atmosphere is dangerous to human's health. The result of this research indicated that people with trees within their houses enjoy tree shades as reported by (Heisler et al., 1995) [12] and (Ulrich 1984) [13] pointed out; tree shade reduces ultraviolet radiation and its associated health problems. Tree leaves have the capacity to filter air which can improve the health condition of the people within the city and reduce air pollutants as reported by (Nowak et al., 2006) [14] that trees improve air quality by lowering air temperatures, altering emissions from building energy use and other sources, and removing air pollutants through their leaves. It was also gathered that trees are used as wind break and provide fruits for the people's nutritional intake as reported by (Fuwape and Onyekwelu, 2011) [15] the traditionally, people planted trees around their houses for fruits, nuts, leaves, fuel wood, fodder, building materials and windbreaks. 
Table 1a. Tree Species Distribution and Diversity within Ibadan Metropolis (Urban), Ibadan

\begin{tabular}{|c|c|c|c|c|c|c|c|c|c|c|}
\hline $\mathrm{S} / \mathrm{N}$ & Tree species & Family & Freq. & $\mathrm{MHt}$ & MDbh & B.A & Vol. & $\mathrm{RD}$ & $\mathrm{RD}_{\mathrm{O}}$ & IVI \\
\hline 1 & Adansonia digitata & Bombacaceae & 1 & 12.0 & 17.10 & 0.35 & 4.24 & 0.80 & 2.11 & 0.84 \\
\hline 2 & Albizia ferruginea & Mimosoideae & 1 & 12.7 & 14.02 & 0.32 & 4.09 & 0.80 & 1.92 & 0.77 \\
\hline 3 & Albizia lebbeck & Mimosoideae & 1 & 10.5 & 15.10 & 0.33 & 3.50 & 0.80 & 1.98 & 0.79 \\
\hline 4 & Albizia zygia & Mimosoideae & 2 & 11.0 & 16.40 & 0.35 & 3.81 & 1.60 & 2.06 & 1.65 \\
\hline 5 & Astonia boonei & Apocynaceae & 1 & 12.8 & 31.10 & 0.52 & 6.61 & 0.80 & 3.08 & 1.23 \\
\hline 6 & Azadirachta indica & Meliaceae & 15 & 14.2 & 16.41 & 0.35 & 4.92 & 12.00 & 2.06 & 12.38 \\
\hline 7 & Bombax buonopozense & Bombacaceae & 1 & 16.5 & 28.15 & 0.48 & 7.92 & 0.80 & 2.86 & 1.14 \\
\hline 8 & Borassus aethiopum & Arecaceae & 1 & 12.3 & 11.91 & 0.41 & 5.00 & 0.80 & 2.42 & 0.97 \\
\hline 9 & Calitris intertropical & Cactaceae & 1 & 10.4 & 20.36 & 0.51 & 5.28 & 0.80 & 3.02 & 1.21 \\
\hline 10 & Callitris intratropica & Cupressaceae & 1 & 10.0 & 18.20 & 0.48 & 4.80 & 0.80 & 2.86 & 1.14 \\
\hline 11 & Casuarina equisetifolia & Casuarinaceae & 1 & 17.8 & 14.50 & 0.44 & 7.76 & 0.80 & 2.60 & 1.04 \\
\hline 12 & Ceiba pentandra & Malvaceae & 1 & 13.6 & 27.10 & 0.60 & 8.10 & 0.80 & 3.55 & 1.42 \\
\hline 13 & Cocos nucifera & Arecaceae & 3 & 12.5 & 14.61 & 0.44 & 5.47 & 2.40 & 2.60 & 3.13 \\
\hline 14 & Delonix regia & Fabaceae & 18 & 10.0 & 14.20 & 0.43 & 4.32 & 14.40 & 2.58 & 18.55 \\
\hline 15 & Elaeis guinensis & Palmae & 1 & 8.6 & 18.42 & 0.76 & 6.54 & 0.80 & 4.53 & 1.81 \\
\hline 16 & Erythrina speciosa & Fabaceae & 1 & 11.2 & 16.30 & 0.18 & 1.97 & 0.80 & 1.05 & 0.42 \\
\hline 17 & Eucalyptus camaldulensis & Myrtaceae & 1 & 14.6 & 15.20 & 0.17 & 2.45 & 0.80 & 1.00 & 0.40 \\
\hline 18 & Eucalyptus citriodora & Myrtaceae & 1 & 14.0 & 19.30 & 0.20 & 2.78 & 0.80 & 1.18 & 0.47 \\
\hline 19 & Eucalyptus citrusdorra & Myrtaceae & 1 & 13.8 & 11.84 & 0.14 & 1.99 & 0.80 & 0.86 & 0.34 \\
\hline
\end{tabular}

Table 1a Continued. Tree Species Distribution within Ibadan Metropolis (Urban), Ibadan

\begin{tabular}{|c|c|c|c|c|c|c|c|c|c|c|}
\hline $\mathrm{S} / \mathrm{N}$ & Tree species & Family & Freq. & $\mathrm{MHt}$ & MDbh & B.A & Vol. & $\mathrm{RD}$ & $\mathrm{RD}_{\mathrm{O}}$ & IVI \\
\hline 20 & Eucalyptus torrelliana & Myrtaceae & 1 & 14.6 & 9.26 & 0.13 & 1.86 & 0.80 & 0.76 & 0.30 \\
\hline 21 & Ficus exasperate & Moraceae & 1 & 16.5 & 13.72 & 0.24 & 3.88 & 0.80 & 1.40 & 0.56 \\
\hline 22 & Ficus goliath & Moraceae & 1 & 13.6 & 22.61 & 0.32 & 4.32 & 0.80 & 1.89 & 0.76 \\
\hline 23 & Ficus nitida & Moraceae & 3 & 10.8 & 22.43 & 0.32 & 3.41 & 2.40 & 1.88 & 2.26 \\
\hline 24 & Gliricidia sepium & Fabaceae & 5 & 10.3 & 17.56 & 0.27 & 2.77 & 4.00 & 1.60 & 3.21 \\
\hline 25 & Gmelina arborea & Verbenaceae & 6 & 14.8 & 15.18 & 0.25 & 3.67 & 4.80 & 1.48 & 3.54 \\
\hline 26 & Hildegardia barterii & Meliaceae & 2 & 8.6 & 23.30 & 0.32 & 2.79 & 1.60 & 1.93 & 1.55 \\
\hline 27 & Hura crepitans & Euphorbiaceae & 1 & 11.6 & 11.9 & 0.22 & 2.55 & 0.80 & 1.31 & 0.52 \\
\hline 28 & Khaya grandifoliola & Meliaceae & 1 & 18.8 & 26.14 & 0.35 & 6.66 & 0.80 & 2.11 & 0.84 \\
\hline 29 & Khaya senegalensis & Meliaceae & 1 & 12.6 & 15.10 & 0.25 & 3.11 & 0.80 & 1.47 & 0.59 \\
\hline 30 & Lannea welwitschii & Anacardiaceae & 1 & 16.4 & 28.10 & 0.38 & 6.15 & 0.80 & 2.23 & 0.89 \\
\hline 31 & Malus domestica & Rosaceae & 1 & 10.0 & 16.52 & 0.26 & 2.60 & 0.80 & 1.55 & 0.62 \\
\hline 32 & Mangifera indica & Anacardiaceae & 2 & 13.6 & 19.10 & 0.28 & 3.86 & 1.60 & 1.69 & 1.35 \\
\hline 33 & Milicia excela & Moraceae & 2 & 12.9 & 22.21 & 0.31 & 4.05 & 1.60 & 1.87 & 1.50 \\
\hline 34 & Millettia regia & Moraceae & 1 & 14.0 & 9.48 & 0.20 & 2.80 & 0.80 & 1.19 & 0.48 \\
\hline 35 & Millettia thonningii & Papilionioideae & 2 & 16.2 & 22.20 & 0.31 & 5.08 & 1.60 & 1.87 & 1.49 \\
\hline 36 & Morinda lucida & Rubiaceae & 1 & 8.6 & 8.72 & 0.19 & 1.67 & 0.80 & 1.16 & 0.46 \\
\hline 37 & Newbouldia laevis & Bignoniaceae & 1 & 10.2 & 10.56 & 0.21 & 2.13 & 0.80 & 1.24 & 0.50 \\
\hline
\end{tabular}


Table 1a Continued: Tree Species Distribution within Ibadan Metropolis (Urban), Ibadan

\begin{tabular}{|c|c|c|c|c|c|c|c|c|c|c|}
\hline S/N & Tree species & Family & Freq. & MHt & MDbh & B.A & Vol. & RD & RD & IVI \\
\hline 38 & Parkia biglobosa & Mimosaceae & 1 & 12.4 & 12.49 & 0.22 & 2.79 & 0.80 & 1.34 & 0.54 \\
\hline 39 & Phyllantus discoides & Euphorbiaceae & 2 & 12.0 & 19.21 & 0.28 & 3.42 & 1.60 & 1.70 & 1.36 \\
\hline 40 & Pinus Caribbean & Pinaceae & 1 & 12.8 & 10.40 & 0.21 & 2.66 & 0.80 & 1.24 & 0.49 \\
\hline 41 & Pinus oocarpa & Pinaceae & 2 & 12.1 & 17.50 & 0.27 & 3.25 & 1.60 & 1.60 & 1.28 \\
\hline 42 & Plumeria alba & Apocynaceae & 2 & 10.2 & 9.18 & 0.20 & 2.02 & 1.60 & 1.18 & 0.94 \\
\hline 43 & Polyalthia longifolia & Annonaceae & 5 & 14.8 & 16.12 & 0.26 & 3.79 & 4.00 & 1.53 & 3.05 \\
\hline 44 & Pterocarpus macrocarpus & Papilionioideae & 1 & 11.5 & 16.10 & 0.26 & 2.95 & 0.80 & 1.53 & 0.61 \\
\hline 45 & Pycnanthus angolensis & Myristicaceae & 2 & 14.6 & 16.18 & 0.26 & 3.75 & 1.60 & 1.53 & 1.22 \\
\hline 46 & Ricinodendron heudelotii & Euphorbiaceae & 1 & 12.0 & 16.19 & 0.26 & 3.08 & 0.80 & 1.53 & 0.61 \\
\hline 47 & Roysonea regia & Arecacea & 1 & 12.6 & 18.10 & 0.27 & 3.46 & 0.80 & 1.63 & 0.65 \\
\hline 48 & Roystonea oleracea & Arecaceae & 1 & 12.0 & 18.10 & 0.27 & 3.29 & 0.80 & 1.63 & 0.65 \\
\hline 49 & Senna siamea & Fabaceae & 3 & 10.0 & 23.12 & 0.32 & 3.23 & 2.40 & 1.92 & 2.31 \\
\hline 50 & Tectona grandis & Lamiaceae & 12 & 12.4 & 14.50 & 0.24 & 3.00 & 1.60 & 1.44 & 1.15 \\
\hline 51 & Terminalia catappa & Combretaceae & 15 & 10.2 & 23.20 & 0.32 & 3.30 & 4.00 & 1.93 & 3.86 \\
\hline 52 & Terminalia ivorensis & Combretaceae & 17 & 11.2 & 26.10 & 0.35 & 3.96 & 5.60 & 2.11 & 5.90 \\
\hline 53 & Terminalia superba & Combretaceae & 2 & 14.8 & 16.21 & 0.26 & 3.80 & 1.60 & 1.53 & 1.22 \\
\hline 54 & Triplochiton scleroxylon & Sterculiaceae & 1 & 15.8 & 19.37 & 0.29 & 4.52 & 0.80 & 1.71 & 0.68 \\
\hline & & & 155 & & & 16.8 & 211.2 & & & \\
\hline
\end{tabular}

Freq - number of tree stems in the city, B.A. - Basal area of trees in the city, Vol. - Volume of trees in the city.

Table 1b. Tree Species Distribution and Diversity in Omi-Adio (Peri-Urban), Ibadan

\begin{tabular}{|c|c|c|c|c|c|c|c|c|c|c|}
\hline $\mathrm{S} / \mathrm{N}$ & Tree species & Family & Freq. & MHt & MDbh & B.A & Vol. & $\mathrm{RD}$ & $\mathrm{RD}_{\mathrm{O}}$ & IVI \\
\hline 1 & Albizia lebbeck & Fabaceae & 2 & 14.0 & 34.6 & 0.30 & 4.23 & 1.98 & 1.64 & 1.81 \\
\hline 2 & Astonia boonei & Apocynaceae & 1 & 21.0 & 22.9 & 0.38 & 7.97 & 0.99 & 2.06 & 1.52 \\
\hline 3 & Azadirachta indica & Meliaceae & 11 & 8.6 & 38.8 & 0.47 & 4.05 & 10.89 & 2.55 & 6.72 \\
\hline 4 & Cocos nucifera & Arecaceae & 6 & 11.1 & 38.6 & 0.28 & 3.16 & 5.94 & 1.54 & 3.74 \\
\hline 5 & Elaeis guinensis & Palmae & 8 & 12.8 & 47.9 & 1.00 & 12.82 & 7.92 & 5.42 & 6.67 \\
\hline 6 & Ficus exasperate & Moraceae & 3 & 11.2 & 59.8 & 0.86 & 9.66 & 2.97 & 4.67 & 3.82 \\
\hline 7 & Gliricidia sepium & Fabaceae & 22 & 7.9 & 34.9 & 0.27 & 2.16 & 21.78 & 1.48 & 11.63 \\
\hline 8 & Gmelina arborea & Verbenaceae & 5 & 18.0 & 82.8 & 3.66 & 65.97 & 4.95 & 19.85 & 12.40 \\
\hline 9 & Khaya senegalensis & Meliaceae & 1 & 19.3 & 74.8 & 2.69 & 51.89 & 0.99 & 14.56 & 7.78 \\
\hline 10 & Mangifera indica & Anacardiaceae & 1 & 14.4 & 46.9 & 0.78 & 11.22 & 0.99 & 4.22 & 2.61 \\
\hline 11 & Militia thonningii & Cactaceae & 2 & 9.6 & 52.5 & 0.82 & 7.85 & 1.98 & 4.43 & 3.20 \\
\hline 12 & Morinda lucida & Rubiaceae & 1 & 10.2 & 22.1 & 0.17 & 1.77 & 0.99 & 0.94 & 0.97 \\
\hline 13 & Newbouldia laevis & Bignoniaceae & 1 & 16.0 & 67.4 & 2.90 & 46.33 & 0.99 & 15.69 & 8.34 \\
\hline 14 & Senna siamea & Mimosaceae & 2 & 11.2 & 49.2 & 0.88 & 9.88 & 1.98 & 4.78 & 3.38 \\
\hline 15 & Pycnanthus angolensis & Myristiceae & 7 & 7.1 & 43.8 & 0.42 & 2.96 & 6.93 & 2.26 & 4.60 \\
\hline 16 & Ricinodendron heudelotii & Euphorbiaceae & 2 & 11.6 & 38.9 & 0.81 & 9.44 & 1.98 & 4.41 & 3.19 \\
\hline 17 & Senna siamea & Fabaceae & 4 & 10.8 & 24.6 & 0.20 & 2.15 & 3.96 & 1.08 & 2.52 \\
\hline 18 & Tectona grandis & Lamiaceae & 18 & 11.8 & 34.1 & 0.68 & 8.02 & 17.82 & 3.68 & 10.75 \\
\hline \multirow[t]{2}{*}{19} & Triplochiton scleroxylon & Malvaceae & 4 & 15.7 & 43.2 & 0.88 & 13.80 & 3.96 & 4.76 & 4.36 \\
\hline & & & 101 & & & 18.5 & 275.3 & & & \\
\hline
\end{tabular}

Freq - number of tree stems in the city, B.A. - Basal area of trees in the city, Vol. - Volume of trees in the city.

Demographic Characteristics of Respondents in Relation to Socio-Economic Livelihood in Ibadan

Demographic characteristics of respondents, gender, marital status, age, and educational attainment from urban forest were presented (Table 2). The result of gender reveal that male has the highest percentage ranging from (77.1 and $85.8 \%$ ), compared to the percentage of female which ranges between (14.2 and 22.9\%) within the study area. The percentage of those that are married ranges between 51.4 and $60.0 \%$, while those that are single has 28.6 and $34.3 \%$ and 
the widowed has the least percentage with $11.4-14.3$ within urban and peri-urban respectively. The percentage age of respondents between the age of 21 - 30 ranges between 25.7 and $34.3 \%$, those between the age of $31-40$ has the highest percentage ranges between 37.1 and $45.7 \%$ while those in their middle age between $41-50$ has 5.7 and $28.6 \%$. The elderly with age $51-60$ has percentage ranging between 2.9 and $5.7 \%$ and aged above 60 years has 2.9 and $11.4 \%$ within the urban and peri-urban respectively. The percentage of respondents with no formal education ranges between 5.7 and $28.6 \%$, those with primary education has percentage between 20.0 and $22.9 \%$. Percentage of respondents with secondary education ranges between 37.1 and $40 \%$, while those with tertiary education ranges between 14.3 and $31.4 \%$ within urban and peri-urban respectively. Percentage income generation with less than $\$ 10,000$ has the highest 28.6 and $51.4 \%$ while respondents between $\$ 10,000$ - $\$ 30,000$ have 28.6 and $37.1 \%$. Respondents with income generation between $\mathrm{N} 31,000$ - $\mathrm{N} 50,000$ has 11.4 and $14.3 \%$, while those with income between $\$ 51,000$ - $\$ 70,000$ (5.7 and $11.4 \%$ ). Percentage of respondents with income greater than $\$ 70,000$ has 2.9 and $8.6 \%$ within urban and peri-urban sector respectively. This result shows that there is higher percentage of male respondents involved in urban forest than the female in both the urban and peri-urban section of the town. This means that more products will be sold and this support what Cunningham et al. (2008) [16] noted that male household heads generally have a tendency to sell more output than female household heads, irrespective of the type of crop. Majority of the respondents are between the ages of $30-50$ which is an indication that they are within the active age of the life. These findings agree with the result of Adekunle and Agbaje (2012) [17] which reported that large population of active working age group in the society might lead to pressure on the forest resources. Higher percentage of respondents about $51 \%$ earned less than or $\$ 10,000$ per month from the sale of fruits. This findings affirmed the general statement that a large number of Africans especially Nigerians are living below 1USD per day as reported by (Adekunle et al., 2013) [18]. This is an indication that majority of this people will depend on other sources of income to enhanced the life.

\section{Relationship between the Income Generated and Demographic Variables}

Table 3 shows the relationship between the level of income generation and demographic variables as indicated by the correlation coefficient values obtained. In this table there is high level of negative and insignificant correlation coefficient values which exist between almost all the demographic variables and the level of income obtained from urban forests. Marital status indicate positive value but not significant with correlation coefficient of 0.131 . Highest correlation coefficient value $(0.133)$ which was positive and insignificant was obtained between age of respondents and level of income generated from the study, while the least coefficient $(-0.005)$ negative and insignificant was obtained between education status of respondents and the religion of respondents within urban and peri-urban forest. This result reveals that most respondents do not generate income from trees around their houses and within streets but derive other pleasures from urban forests. Kant (2003) [19] reported that ecosystem capital is valuable to human society not only for the products which may be thought of as commodities, that it contributes to the economic system but also for its functional contributions to the well-being of humanity.

Table 2. Demographic Information of Respondents in Ibadan (Urban and Peri-urban)

\begin{tabular}{|c|c|c|c|c|c|}
\hline & & \multicolumn{2}{|c|}{ Urban } & \multicolumn{2}{|c|}{ Peri-Urban } \\
\hline & & Frequency & $\begin{array}{l}\text { Percent } \\
\text { age }\end{array}$ & $\begin{array}{l}\text { Frequenc } \\
\mathrm{y}\end{array}$ & $\mathrm{e}^{\text {Percentag }}$ \\
\hline \multirow{2}{*}{ Gender } & Male & 30 & 85.8 & 27 & 77.1 \\
\hline & Female & 5 & 14.2 & 8 & 22.9 \\
\hline \multirow{3}{*}{ Marital status } & Single & 12 & 34.3 & 10 & 28.6 \\
\hline & Married & 18 & 51.4 & 21 & 60.0 \\
\hline & Widowed & 5 & 14.3 & 4 & 11.4 \\
\hline \multirow{5}{*}{ Age } & $21-30$ & 9 & 25.7 & 12 & 34.3 \\
\hline & $31-40$ & 13 & 37.1 & 16 & 45.7 \\
\hline & $41-50$ & 10 & 28.6 & 2 & 5.7 \\
\hline & $51-60$ & 2 & 5.7 & 1 & 2.9 \\
\hline & $>60$ & 1 & 2.9 & 4 & 11.4 \\
\hline \multirow{4}{*}{ Education Status } & No formal education & 2 & 5.7 & 10 & 28.6 \\
\hline & Primary education & 8 & 22.9 & 7 & 20.0 \\
\hline & Secondary education & 14 & 40.0 & 13 & 37.1 \\
\hline & Tertiary education & 11 & 31.4 & 5 & 14.3 \\
\hline \multirow{5}{*}{ Income Level } & $<10,000$ & 18 & 51.4 & 10 & 28.6 \\
\hline & $10,000-30,000$ & 10 & 28.6 & 13 & 37.1 \\
\hline & $31,000-50,000$ & 4 & 11.4 & 5 & 14.3 \\
\hline & $51,000-70,000$ & 2 & 5.7 & 4 & 11.4 \\
\hline & $>70,000$ & 1 & 2.9 & 3 & 8.6 \\
\hline
\end{tabular}


Table 3. Correlation Coefficient for Demographic Variables and Income Generation from Urban Forests

\begin{tabular}{|c|c|c|c|c|c|c|}
\hline & Gender & Marital Status & Age & Religion & Educational Status & Income Level \\
\hline Gender & 1 & & & & & \\
\hline Marital Status & .131 & 1 & & & & \\
\hline Age & -.026 & $-.445^{* *}$ & 1 & & & \\
\hline Religion & $-.256^{*}$ & -.054 & -.053 & 1 & & \\
\hline Educational Status & -.098 & $-.248^{*}$ & -.213 & -.005 & .092 & \\
\hline Income Level & -.057 & .054 & .133 & .024 & .092 & 1 \\
\hline
\end{tabular}

* means correlation is significant at the 0.05 level

** means correlation is significant at the 0.01 level

Table 4. Biodiversity indices and growth variables of tree species in Ibadan Metropolis

\begin{tabular}{|l|c|c|c|c|c|}
\hline & Urban & Peri-Urban & & Urban & Peri-Urban \\
\hline \multicolumn{1}{|c|}{ Biodiversity Indices } & Values & Values & Tree Growth Variables & Values & Values \\
\hline No. of tree Species & 54 & 19 & No. of tree stem & 155 & 101 \\
\hline No. of family & 25 & 16 & Mean Dbh $(\mathrm{cm})$ & 56.4 & 74.8 \\
\hline Shannon-Weiner Index $\left(\mathrm{H}^{\prime}\right)$ & 3.35 & 2.48 & Mean Height $(\mathrm{m})$ & 17.8 & 19.3 \\
\hline Pielou's Evenness Index $\left(\mathrm{E}_{\mathrm{H}}\right)$ & 0.84 & 0.84 & Total basal area $\left(\mathrm{m}^{2}\right)$ & 22.8 & 18.5 \\
\hline Maximum diversity index $\left(\mathrm{H}_{\mathrm{Max}}\right)$ & 3.99 & 2.94 & Total Volume $\left(\mathrm{m}^{3}\right)$ & 284.8 & 275.3 \\
\hline
\end{tabular}

\section{Conclusions and Recommendation}

The results of this research revealed the level of tree species diversity and population in Ibadan. The species diversity and abundance cannot be compared with some similar forest ecosystem in the tropical rainforest ecosystem. This city therefore needs improved conservation, management effort and intense research on biodiversity indicators in Nigerians city. Tree species with low richness and diversity should be considered as species that is about to extinct. Serious conservation effort should be geared for such species to prevent them from going to extinction. The result of this research will serve as baseline information and data that can be helpful in the appraisal and evaluation of plant resources within Ibadan as one of the tropical rainforest ecosystem city for its effective management. The continuous involvement of individuals, institutions, private organizations and non-governmental organization should be adequately rewarded to encourage them to do more in terms of tree planting in and around their buildings and the city. This study yields a list of species that contribute to the beautification of the streets, creates shades on the walk ways, protect houses and serve as avenues trees which tend to reduce harsh condition of the environment. The people should be educated and encouraged on the planting of exotic tree species which is fast growing. Seedlings should be made available for any individual or group of individuals that are interested in having trees around their houses or buildings as a form of encouragement.

\section{Acknowledgements}

This research was supported by the International
Foundation for Science (IFS), Stockholm, Sweden, through a grant to Agbelade, Aladesanmi Daniel.

\section{REFERENCES}

[1] Nowak, D. J., Noble, M. H., Sisinni, S. M., Dwyer, J. F., (2001). Assessing the U.S. urban forest resource. Journal of Forestry 99 (3), 37 - 42.

[2] Keystone Center (1991). Biological diversity on federal lands: Report of a keystone centre, Keystone Co. 96.

[3] McPherson EG, Simpson JR (1999). Carbon dioxide reduction through urban forestry: guidelines for professional and volunteer tree planters. Gen. Tech. Rep. PSW-171, USDA Forest Service, Pacific Southwest Research Station, Albany, CA. 237 pp.

[4] Millennium Ecosystem Assessment (MEA) (2005): Ecosystem and human well- being. Island Press, Washington. DC. pp. 167- 180. http://www.MEA.org.

[5] Keay, R.W.J., (1989). Trees of Nigeria. Oxford University Press, Oxford, $476 \mathrm{pp}$.

[6] Husch, B., T. W. Beers \& Jr. J. A. Keenshaw. (2003). Forest Mensuration. 4th edn. John Wiley \& Sons Inc., New Jersey, USA.

[7] Brashears, M. B., M. A. Fajvan, and T.M. Schuler (2004). An Assessment of Canopy Stratification and Tree Species Diversity Following Clearcutting in Central Appalachian Hardwoods. Forest Science. 50(1):54-64.

[8] Aidar, M.P.M., Godoy, J.R.L., Bergmann, J. and Joly, C.A. (2001). Atlantic forest succession over calcareous soil, Parque Estadual Turísitico do Alto Ribeira PETAR, SP. Revista Brasileira de Botânica 24:455-469. 
[9] Kent Martin and Coker, Paddy (1992). Vegetation Description and Analysis: A Practical Approach. John Wiley \& Sons: New York.

[10] Guo, F.Q., Okamoto, M., and Crawford, N.M. (2003). Identification of a plant nitric oxide synthase gene involved in hormonal signaling. Science 302: 100-103.

[11] Onyekwelu, J.C; R, Mosandl; B. Stimm (2007). Tree Species Diversity and Soil Status of Two Natural Forest Ecosystems in Lowland Humid Tropical Rainforest Region of Nigeria. Conference on International Agricultural Research for Development (Tropentag 2007). 4pp

[12] Heisler, G.M.; Grant, R.H.; Grimmond, S.; Souch, C.1995. Urban forests cooling our communities? In: Kollin, C.; Barratt, M., eds. Proceedings: $7^{\text {th }}$ national urban forest conference. Washington, DC: American Forests: 31-34.

[13] Ulrich, R.S. (1984). View through a window may influence recovery from surgery. Science. 224:420-421.

[14] Nowak D.J., Crane D.E., and Stevens J.C., (2006). Air pollution removal by urban trees and shrubs in the United State. Urban Forestry and Urban Greening 4:115-12.

[15] Fuwape, J. A., \& Onyekwelu, J. C (2011). Urban Forest Development in West Africa: Benefits and Challenges. Journal of Biodiversity and Ecological Sciences, 1(1), 77-94.

[16] Cunningham, LT, Brown, BW, Anderson, KB \& Tostao, E, 2008. Gender differences in marketing styles. Agricultural Economics 38(1), 1-7.

[17] Adekunle M. F. and Agbaje B. M. (2012). Public willingness to pay for ecosystem service functions of a peri-urban forest near Abeokuta, Ogun State, Nigeria. J. Dev. Agric. Econ. $4(2): 45-46$

[18] Adekunle VAJ, Olagoke A.O. and Akindele S. O. (2013). Tree species diversity and structure of a Nigerian strict nature reserve. Tropical Ecology 54(3):275-289.

[19] Kant S. (2003). Choices of Ecosystem Capital without Discounting and Prices Environmental Monitoring and Assessment 86: 105-127. 